\begin{tabular}{|l|l|}
\hline $\begin{array}{l}\text { Postprint } \\
\text { Version }\end{array}$ & 1.0 \\
\hline $\begin{array}{l}\text { Journal website } \\
\text { Pubmed link }\end{array}$ & $\underline{\text { http://dx.doi.org/10.1016/S0304-3959(98)00117-1 }}$ \\
\hline DOI & $\underline{10.1016 / \text { S0304-3959(98)00117-1 }}$ \\
\hline
\end{tabular}

This is a NIVEL certified Post Print, more info at http://www.nivel.eu

\title{
Prevalence of chronic benign pain disorder among adults: a review of the literature
}

\author{
Peter F.M. VerhaAK ${ }^{\mathrm{A}}{ }^{*}$, JAN J. KersSens ${ }^{\mathrm{A}}$, JoOst DeKKER ${ }^{\mathrm{A}}$, MARJOLIJN J. SORBI ${ }^{\mathrm{B}}$, \\ JOZIEN M. BENSING ${ }^{\mathrm{A}, \mathrm{B}}$
}

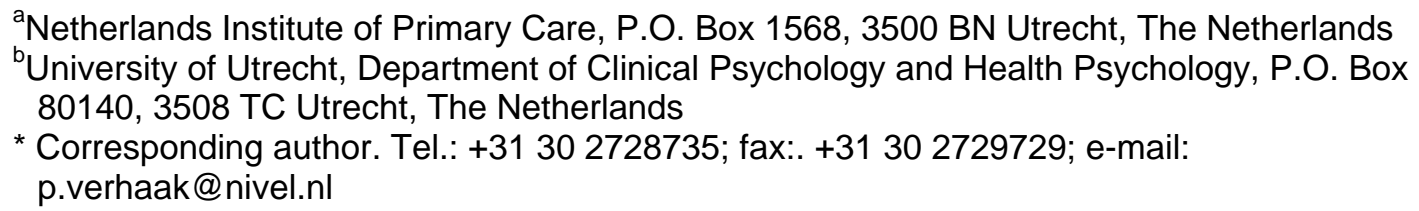

\begin{abstract}
In this review epidemiological studies concerning chronic benign pain among adults are discussed. To this end, studies focusing on chronic pain, reporting prevalences at a population or primary health care level, including subjects aged between 18 and 75 years have been collected and analyzed. Focus of analysis was on research methods, definitions of chronic benign pain used, and reported prevalences. Prevalences varied between $2 \%$ and $40 \%$ of the population. Nor method used (telephone survey, postal survey, nor definition of chronicity ( $>1$ month; $>3$ months; $>6$ months) clearly explained the differences in prevalence in the various studies. Implications for future research are discussed.
\end{abstract}

\section{INTRODUCTION}

Pain has been defined as 'an unpleasant sensory and emotional experience associated with actual and potential tissue damage, or described in terms of such damage' (IASP, 1986). This definition refers to a number of aspects that complicate the study of the epidemiology of pain. For example, the definition refers to 'actual and potential tissue damage', which excludes the possibility of a decisive objective test as a gold standard. Moreover, the definition stresses the subjective character of pain by referring to 'unpleasant sensory and emotional experiences'. Chronic pain is defined by the IASP as 'pain, that persists beyond the normal time of healing (...)', but what exactly is meant by the term 'normal time'? Whereas acute pain is functional and can be considered a mainly physiological response to tissue damage, chronic pain involves psychological and behavioral mechanisms in addition to physiological mechanisms. This complex and subjective character of pain is illustrated by Loeser's model (presented by Raspe and Kohlmann, 1994) of the components of pain (see Fig. 1).

In this model, the physical origin of pain is at core and is surrounded by successive layers of 'pain experience' and 'suffering', ending at the most derived level, 'pain behavior'. Each 
Verhaak, P.F.M., Kerssens, J.J., Dekker, J., Sorbi, M.J., Bensing, J.M. Prevalence of chronic benign pain disorder among adults: a review of the literature. Pain: 1998, 77, 231-239

succeeding layer introduces a certain 'noise', because it is determined not only by pain but also by 'toughness', cultural values, and secondary gains. In acute pain there is a straightforward relation between nociception, pain, suffering, and pain behavior, but in chronic pain this direct link with a nociceptive substrate is not always present. When there is no such link, we refer to chronic benign pain. Related terms found in the literature are idiopathic pain (von Knorring and Ekselius, 1994) and somatoform pain, both of which refer to psychiatric categories in the third version of the Diagnostic and Statistical Manual of Mental Disorders (DSM). In the fourth version (DSM-IV) chronic pain without an organic explanation is categorized as Chronic Pain Disorder Associated with Psychological Factors.

Patients suffering from chronic benign pain experience pain sensations which cannot be explained by physical lesions or physiological dysfunctioning. In such cases, pain behavior might be a dysfunctional remnant of a previously functional behavior. Lousberg (1994) summarized three psychological models that explain how chronic pain is maintained. In the operant conditioning model, 'pain behavior' that was once functional can come under the control of positive or negative reinforcers, such as attention of the partner or removal of duties. In the antecedent control of pain model, pain might occur as a response to a physical stimulus, for example muscle tension that was previously associated with a nociceptive stimulus. In the cognitive-behavioral model, pain is associated with maladaptive cognitions such as feelings of helplessness or catastrophizing.

The complex nature of chronic benign pain means that its prevalence cannot be measured by means of assessing wellcircumscribed physical conditions, as is the case with diabetes or malaria. It requires a multidimensional approach incorporating a number of dimensions such as the localization of pain, pain intensity, temporal characteristics, affective appraisal, coping, and grading of pain (see VonKorff et al., 1990; Turk and Rudy, 1992; Raspe and Kohlmann, 1994). Yet despite these difficulties in measuring the prevalence of chronic pain, forceful statements have been made about the prevalence and the costs and impact on social security systems of chronic pain. The statement that 'Chronic pain is a major health problem and it has been estimated that between $25 \%$ and $30 \%$ of the populations in industrialized countries have chronic pain' opened an editorial in the British Journal of General Practice in 1992 (Seers, 1992), and 'Although precise data are lacking for the Netherlands, it is reported that 10000 new cases (patients who are unable to work because of pain) are registered each year' (Lousberg, 1994). Aronoff et al. (1983) estimated that chronic pain costs the United States 40 billion dollars a year. Nachemson (1994) wrote of the situation in Sweden: 'Together with all the other chronic pain syndromes for which physicians have no proper explanation..., the statement that the cost of these conditions might cause the end of the welfare state might not be untrue'. In fact, based on current knowledge and existing figures it is not possible to give a reliable estimate of the prevalence of chronic pain. Because of this lack of reliable figures, the Dutch National Council of Research for Medical Sciences commissioned the Netherlands Institute of Primary Health Care to estimate the prevalence of chronic benign pain disorder among adults. To this end, we reviewed the literature on the epidemiology of chronic benign pain among adults, paying attention to the methodology used to assess the prevalence of chronic benign pain, the definitions and inclusion criteria, other descriptive factors, and, lastly, the prevalence determined.

\section{[FIGURE 1]}

\section{METHOD}

\subsection{Inclusion and exclusion criteria}

To be included in this review, studies had to meet the following inclusion criteria: they should focus on chronic pain; they should have an epidemiological character, reporting prevalence at a population or primary health care level; and they should include subjects 
aged between 18 and 75 years. Moreover, because the characteristic 'benign' is seldom mentioned explicitly, we included all epidemiological studies concerning pain, as long as the study was not exclusively focused on acute pain or on pain as a consequence of a defined disease, such as cancer or rheumatoid arthritis. Studies that concerned exclusively children or elderly people and which focused on cancer or arthritis were excluded. Because we wanted to focus on methodological and definition problems associated with the measurement of chronic benign pain, we did not formulate methodological or definitional criteria beforehand.

\subsection{Search strategy}

We searched the databases Medline and Embase for 1990 to 1996, using the key words 'chronic pain' and 'epidemiology' with exclusion of the key words 'children' and 'cancer'. We then continued with the traditional 'snowball method' by looking for references in recent publications, especially reviews and editorials on pain research (Von- Korff, 1992; Crombie, 1994; Oosterhof and Brueren, 1994; Raspe and Kohlmann, 1994). This search identified 15 empirical studies which had assessed the prevalence of chronic pain in a general population.

\section{RESULTS}

\subsection{General characteristics}

The studies included in our review are presented in Appendix A, together with their relevant characteristics. The studies were from the USA (4), UK (3), Denmark (2), Sweden (2), Canada, Finland, Germany, and New Zealand (1 each). Although the publications are from 1984 to 1994, the oldest survey included (NHANES: First National Health And Nutrition Examination Survey) stems from the early seventies. Most data were collected between 1980 and 1990. Thirteen of the studies were population surveys; in two studies general practitioners screened their visiting patients during a certain period. Three studies were restricted to pain in specific body regions (musculoskeletal pain (2) and abdominal pain (1)); the other 12 studies investigated pain in general. Two studies (Magni et al., 1990, 1992) are comparable in method but concerned with two specific body regions. We will treat them in the following as one. The studies involved between 308 to more than 10000 subjects.

\subsection{Research methods}

Four main research methods were used: (1) the telephone survey, which was used in three studies. In two studies (Bowsher et al., 1991; Crook et al., 1984), the data collected concerned the person who answered the telephone and other members of the household, which might have led to underreporting of pain for the other members of the household; (2) the postal questionnaire, which was used in six studies; (3) interview with participant, which was used in three studies; and (4) expert assessments, in which general practitioners assessed the patients with pain in the attending population (Frølund and Frølund, 1986; Potter and Jones, 1992), or in which physicians working in mobile clinics examined patients (Mäkélä and Heliövaara, 1991).

The use of different methods appeared to lead to differences in non-response. For example, in the studies by Frluolund and Frølund (1986) and Potter and Jones (1992), each visiting patient was in principle eligible. The study of Mäkélä and Heliövaara (1991) had a participation rate of $90 \%$. The only information for the response rate for the telephone surveys was 95\% in the study by Crook et al. (1984). The postal and interview studies had a lower response rate of $77 \%$ on average.

\subsection{Definitions of chronic benign pain}

'Pain' was defined in terms of its intensity (Brattberg et al., 1989; Andersson, 1994), duration (24 hours or longer; VonKorff et al., 1988; Potter and Jones, 1992; Croft et al., 1993), or illness behavior (James et al., 1991; 'severe enough to lead to consultation etc.'). Ten studies did not specify the concept of 'pain' further, although all but three used a time 
dimension for 'chronic pain'. Thus 'chronic pain' was defined by the persistence of pain for 1 month (Magni et al., 1990, 1992, 1993; Kohlmann, 1991), 3 months or longer (Frølund and Frølund, 1986; Sternbach, 1986; Bowsher et al., 1991; Croft et al., 1993; Andersson, 1994), and 6 months (VonKorff et al., 1988; Brattberg et al., 1989; Potter and Jones, 1992). James et al. (1991) did not take the duration of pain into consideration but investigated the lifetime prevalence of pain. Crook et al. (1984) limited the conceptualization of chronic pain to 'often troubled by pain’. Mäkélä and Heliövaara (1991) and Andersson (1994) used the term 'chronic' without specifying it.

Frølund and Frølund (1986) referred to 'problem cases', as 'those whose pain problem was considered unsolved pain and perhaps unsolvable'. Some other studies referred to a lack of attribution to 'real diseases' (Bowsher et al., 1991) or to positive associations of chronic pain with tiredness and depression (VonKorff et al., 1988; Magni et al., 1990, 1992; Potter and Jones, 1992; Croft et al., 1993), which might be an indication of the benign character of a substantial number of chronic cases. No study, however, defined the concept 'benign' explicitly.

\subsection{Prevalence of chronic (benign) pain}

The prevalence of chronic (benign) pain is summarized in Table 1, together with selected methodological characteristics. The studies are ranked according to the prevalence of chronic pain (low to high). Some studies gave separate data for pain in distinct locations (Sternbach, 1986; Magni et al., 1990, 1992; Mäkélä and Heliövaara, 1991). A maximum prevalence estimate is the sum of all separate figures (assuming there is no overlap at all) and a minimum prevalence estimate is the highest subscore (assuming maximum overlap). For these studies we give a range instead of one prevalence number.

The lowest and highest estimates for the prevalence of chronic pain are easily explained by the different epidemiological measures used: Potter and Jones (1992) gave the incidence instead of the prevalence, and James et al. (1991) gave the life-time prevalence instead of the point-prevalence. The incidence reported by Potter and Jones is difficult to interpret because the authors reported only the number of patients (20) included in the study. The numerator is unknown, but as it consists of all patients who visited eight general practitioners over a 10month period, we estimate the numerator to be higher than 10000 , yielding an incidence of less than $1 \%$. The prevalence of chronic pain in the other studies varied from $2 \%$ (Kohlmann, 1991) to 40\% (Brattberg et al., 1989). The median of the studies was 15\%.

\section{[TABLE 1]}

\subsection{Methods of measurement and definition}

The definition of 'chronic' used in the various studies could have affected the prevalence estimated. Pain lasting longer than 2 weeks would be expected to be more prevalent than pain lasting longer than 6 months. Moreover, the method by which the data were collected might influence the outcome: a clinical examination by a doctor is more stringent than an answer to a postal questionnaire. Table 2 lists the prevalence of chronic pain according to the different research methods and definitions of chronic pain used in the various studies. See also columns 2 and 3 in Appendix A.

Each method yields high and low prevalences. In each of the rows, distinguishing the different methods, prevalence rates above and below the median of $15 \%$ can be found. The prevalence estimates of chronic pain was not greatly affected by the time definition of chronic pain as well: the second highest prevalence was found when chronic pain was defined as pain present for longer than 6 months, and one of the lowest prevalence rates was recorded in a study in which chronic pain was defined as pain present for 2 weeks to 1 month. The prevalence of chronic pain was high in studies in which chronic pain was not defined or the definition was unclear. 
Verhaak, P.F.M., Kerssens, J.J., Dekker, J., Sorbi, M.J., Bensing, J.M. Prevalence of chronic benign pain disorder among adults: a review of the literature. Pain: 1998, 77, 231-239

As stated in Section 1, a multidimensional approach has been advocated for the measurement of chronic pain. Such an approach should take different aspects into account when defining chronic pain (grading). This was the case for the studies by Frølund and Frølund (1986), VonKorff et al. (1988), Brattberg et al. (1989), and Andersson (1994). Furthermore, we assumed that experts and general practitioner assessors (Mäkélä and Heliövaara, 1991; Potter and Jones, 1992) implicitly take these different aspects into account. The other investigators used a simple definition of chronic pain limited to the affirmative response that pain persisted for a certain period in a certain location. See also column 3 in Appendix A. However, use of a multidimensional 'definition' of chronic pain hardly had any influence on the reported prevalence. The six studies which used a complex definition of chronic pain yielded a median prevalence of $13.5 \%$, and those with a 'simple' definition a prevalence of $16 \%$.

\section{[TABLE 2]}

\subsection{Patient characteristics}

There was more consensus regarding sociodemographic characteristics (see column 6 , Appendix A). In seven studies women were over-represented and in two studies the prevalence of chronic pain was equal for men and women, but in no study was an overrepresentation of men mentioned. Chronic pain generally increased with age, with some studies reporting a peak prevalence between the ages of 45 and 65 years. The prevalence of chronic pain was higher in the lower income groups. The most prevalent pain was musculoskeletal pain (back pain, joint pain), although headache and abdominal pain were also frequently mentioned. When investigated, a positive relation between chronic pain and affective, depressive, or psychological symptoms was found.

\section{DisCUSSION}

Our first aim was to determine which methods have been used to determine the prevalence of chronic benign pain. However, a search of the literature revealed that there have been no epidemiological studies into the prevalence of chronic benign pain in the general population. In fact, there have been few epidemiological studies of chronic pain in the general population. These studies made use of a wide range of definitions and yielded widely varying data for the prevalence of chronic pain. Neither the method of data collection nor the definition of chronic pain seemed to affect the prevalence reported. Eight of the studies included in our review took aspects other than the location of the reported pain into consideration.

This relative lack of epidemiological research affected our second aim, i.e. to determine the prevalence of chronic benign pain. Without doubt, many people suffer from pain to such an extent that they are seriously limited in their daily activities over a considerable period of time. The 15 studies we reviewed yielded a median point prevalence of chronic pain of $15 \%$ in the adult population, with a range from $2 \%$ to $40 \%$. There was some consensus about the characteristics of the patients who suffer from chronic pain: they are rela- tively often middle-aged women from the lower socioeconomic strata. Low back, neck, and shoulder are the body areas most frequently affected. Chronic pain is often associated with depression or other kinds of psychological distress.

It is difficult to explain the wide range in reported pain, but a prevalence of chronic pain of $10 \%$ of the population seems a very cautious estimate. There were no clear-cut differences between prevalence based on self-assessment and on diagnoses made by physicians after a clinical examination. Self-assessment sometimes leads to relatively low figures: the telephone survey carried out by Bowsher et al. (1991) yielded a prevalence of chronic pain of only $7 \%$ and the telephone survey of Crook et al. (1984) yielded a prevalence of $11 \%$, while in the study of Mäkélä and Heliövaara (1991), a thorough medical examination led to a 
Verhaak, P.F.M., Kerssens, J.J., Dekker, J., Sorbi, M.J., Bensing, J.M. Prevalence of chronic benign pain disorder among adults: a review of the literature. Pain: 1998, 77, 231-239

prevalence of chronic musculoskeletal pain of at least $40 \%$. The very low estimate reported by Potter and Jones is probably because they investigated the incidence rather than known cases.

Although the benign character of chronic pain was seldom taken into consideration, some conclusions may be drawn about the extent to which somatic diseases are responsible for reported chronic pain. Frølund and Frølund (1986) identified the most important chronic pain categories as being 'bone/joint' (24\% of all chronic conditions), 'muscle/ ligament' (17\%), 'low back' (13\%), 'headache' (12\%), and gastrointestinal (11\%). With the exception of patients suffering from 'bone/joint' pain, where arthritis might be held responsible for most of the cases, most patients suffering from pain in these categories will suffer from symptoms rather than from demonstrable diseases. The predominance of chronic low back pain and chronic neck pain found by Mäkélä and Heliövaara (1991) in their study suggests the same.

The positive relation between chronic pain and psychological distress (see also Smith, 1992) also points to the 'benign', or better, 'not organically explained' character of pain in a number of cases. Benjamin et al. (1988) reported that pain ratings were higher among patients with a mental illness without an organic pathology than among patients with an organic pathology. One might assume that in a substantial number of cases chronic pain is the expression of depression or other forms of psychological distress. However, the absence of an organic explanation for chronic pain should not automatically lead to a psychiatric diagnosis (Benjamin et al., 1988).

Thus, pain without nociception is difficult to assess. Given the subjective elements involved in the measurement of chronic pain, an objective assessment of its 'real' prevalence seems a contradiction. We thus have to accept that pain as an 'essential' element in the Platonic meaning is an impossible ideal (cf. also Wulff et al., 1986). As Mäkélä and Heliövaara state with respect to fibromyalgia: '...(it) resembles a constellation of stars: its components are real enough but the pattern is in the mind of the beholder.' Therefore, in future research it might be more fruitful not to focus on reaching an as reliable as possible prevalence of pain without nociception but on analyzing the suffering and pain behavior of these patients, without worrying too much about the exact numbers. After all, the important question is not precisely how many patients experience pain each day, but the extent to which pain lead to disability, to loss of working days, to premature incapacity, or to unnecessary medical treatment.

Our current research has a prognostic character. Patients are included if they have experienced pain without a clear physical basis for more than 6 months, as assessed by their general practitioners. These patients will be monitored for 3 years, during which time we hope to learn about the course of several aspects of pain (for example, its intensity, temporal characteristics, and locations), the disabilities it causes in daily life, the medical treatment sought and the costs involved, the behavioral aspects (coping), and the impact on physical and psychosocial well-being. While we recognize that we will not determine the real number of patients with chronic benign pain, we hope that we will improve our understanding of the impact of this pain on the daily life of patients. By this, we will come to an estimation of the proportion of patients with chronic pain who appear to be seriously handicapped by their pain on one moment and of the proportion of patients whose condition will not improve after a number of years. In this way our study may contribute to the knowledge about the impact of chronic pain in the long run.

\section{Acknowledgements}

This literature review is part of a research project, funded by the Netherlands Organization for Scientific Research (Program Chronic Diseases, subprogram Pain) by Grant 940-31-033. 
Verhaak, P.F.M., Kerssens, J.J., Dekker, J., Sorbi, M.J., Bensing, J.M. Prevalence of chronic benign pain disorder among adults: a review of the literature. Pain: 1998, 77, 231-239

\section{REFERENCES}

Andersen, S. and Worm-Pedersen, J., The prevalence of persistent pain in a Danish population, Pain, Suppl. (1987) S332.

Andersson, H.I., The epidemiology of chronic pain in a Swedish rural area, Qual. Life Res., 3 (1994) s19-s26.

Andersson, H.I., Eijlertsson, G., Leden, I. and Rosenberg, C., Chronic pain in a geographically defined general population: studies of differences in age, gender, social class and pain localization, Clin. J. Pain, 9 (1993) 174-182.

Aronoff, G.M., Evans, W.O. and Enders, P.L., A review of follow-up studies of multidisciplinary pain units, Pain, 16 (1983) 1-11.

Benjamin, S., Barnes, D., Berger, S., Clarke, I. and Jeacock, J., The relationship of chronic pain, mental illness and organic disorder, Pain, 32 (1988) 185-195.

Bowsher, D., Rigge, M. and Sopp, L., Prevalence of chronic pain in the British population: a telephone survey of 1037 households, Pain Clin., 4 (1991) 223-230.

Brattberg, G., Thorslund, M. and Wikman, A., The prevalence of pain in a general population. The results of a postal survey in a county of Sweden, Pain, 37 (1989) 215-222.

Croft, P., Rigby, A.S., Boswell, R., Schollum, J. and Silman, A., The prevalence of chronic widespread pain in the general population, J. Rheumatol., 20 (1993) 710-713.

Crombie, I.K., Epidemiological studies in pain research, J. Pain Sociol., 11 (1994) 30-32.

Crook, J. and Tunks, E., Defining the chronic pain syndrome, an epidemiological method,

Adv. Pain Res. Ther., 9 (1985) 870-877.

Crook, J., Rideout, E. and Browne, G., The prevalence of pain complaints in a general population, Pain, 18 (1984) 299-314.

Crook, J., Weir, R. and Tunks, E., An epidemiological follow-up survey of persistent pain sufferers in a group family practice and speciality pain clinic, Pain, 36 (1989) 49-61.

Frølund, F. and Frølund, C., Pain in general practice, Scand. J. Primary Health Care, 4 (1986) 97-100.

IASP, Classification of Chronic Pain. Description of pain syndromes and definitions of pain terms, Pain, Suppl. (1986) S3.

James, F.R., Large, R.G., Bushnell, J.A. and Wells, J.E., Epidemiology of pain in New Zealand, Pain, 44 (1991) 279-283.

Kohlmann, T., Schmerzen in der Lu"becker Bevo"lkerung. Ergebnisse einer bevölkerungsepidemiologischen Studies, Der Schmerz, 5 (1991) 208- 213.

Lousberg, R., Chronic Pain. Multiaxial Diagnostics and Behavioral Mechanisms, Thesis, University of Maastricht, Universitaire Pers Maastricht, 1994.

Magni, G., On the relationship between chronic pain and depression when there is no organic lesion, Pain, 36 (1987) 1-21.

Magni, G., Carldieron, C., Rigatti-Lunchini, S. and Merskey, H., Chronic musculoskeletal pain and depressive symptoms in the general population. An analysis of the 1st National Health and Nutrition Examination Survey data, Pain, 43 (1990) 29-307.

Magni, G., Rossi, M.R., Rigatti-Lunchini, S. and Merskey, H., Chronic abdominal pain and depression. Epidemiologic findings in the United States. Hispanic health and nutrition examination survey, Pain, 49 (1992) 77-85.

Magni, G., Marchetti, M., Moreschi, C., Merskey, H. and Rigatti-Lunchini, S., Chronic musculoskeletal pain and depressive symptoms in the National Health and Nutrition Examination: I. Epidemiologic followup study, Pain, 53 (1993) 163-168.

Mäkélä, M. and Heliövaara, M., Prevalence of primary fibromyalgia in the Finnish population, Br. Med. J., 303 (1991) 216-219.

Nachemson, A., Chronic pain. The end of the welfare state?, Qual. Life Res., 3 (1994) s11s17.

Oosterhof, Sj. and Brueren, M.M., Chronisch benigne pijn, Huisarts Nu, 23 (1994) 251-259.

Potter, R. and Jones, J.M., The evolution of chronic pain among patients with

musculoskeletal problems. A pilot study in primary care, Br. J.

Gen. Pract., 42 (1992) 462-464. 
Raspe, H. and Kohlmann, T., Disorders characterised by pain: a methodological review of population surveys, J. Epidemiol. Community Health, 48 (1994) 531-537.

Seers, K., Chronic non-malignant pain, Br. J. Gen. Pract., 42 (1992) 452- 453.

Smith, G.R., The epidemiology and treatment of depression when it coexists with somatoform disorders, somatization or pain, Gen. Hosp.

Psychiatry, 14 (1992) 265-272.

Sternbach, R.A., Survey of pain in the United States: the Nuprin pain report, Clin. J. Pain, 2 (1986) 49-53.

Turk, D.C. and Rudy, T.E., Classification logic and strategies in chronic pain. In: D.C. Turk and R. Melzack. (Eds.), Handbook of Pain Assessment, Guildford Press, New York, 1992. von Knorring, L. and Ekselius, L., Idiopathic pain and depression, Qual.

Life Res., 3 (1994) s57-s68.

VonKorff, M., Epidemiologic and survey methods: chronic pain assessment. In: D.C. Turk and R. Melzack (Eds.), Handbook of Pain Assessment, Guildford Press, New York, 1992.

VonKorff, M., Dworkin, S.F., Resche, L.Le. and Kruger, A., An epidemiologic comparison of pain complaints, Pain, 32 (1988) 173-183.

VonKorff, M., Dworkin, S.F. and Resche, L.Le., Graded chronic pain status: an epidemiological evaluation, Pain, 40 (1990) 279-291.

VonKorff, M. and Resche, L., Le. and Dworkin, S.F. First onset of common pain symptoms: a prospective study of depression as a risk factor, Pain, 55 (1993) 251-258.

Wulff, H.R., Pedersen, S.A. and Rosenberg, R., Philosophy of Medicine, Blackwell Scientific, Oxford, 1986.

\section{FIGURES AND TABLES}

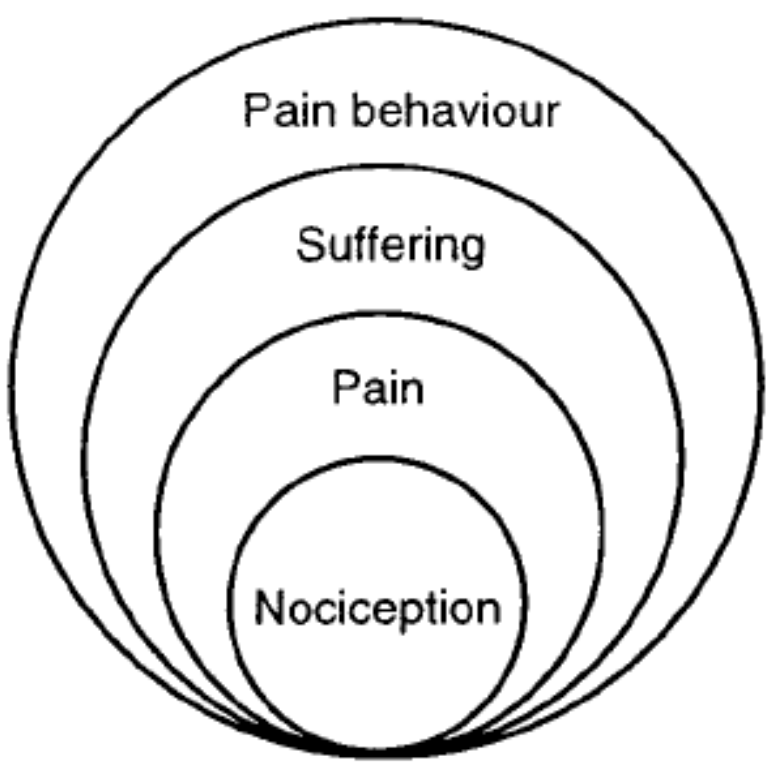

Fig. 1. Loeser's multifaceted model of the components of pain. 


\section{Table 1}

Prevalence of chronic pain

\begin{tabular}{|c|c|c|c|c|}
\hline Authors & Prevalence & $\begin{array}{l}\text { Survey } \\
\text { method }\end{array}$ & $\begin{array}{l}\text { Definition } \\
\text { of chronic }\end{array}$ & $\begin{array}{l}\text { Non- } \\
\text { response }\end{array}$ \\
\hline Potter and Jones, 1992 & $<1 \%{ }^{\mathrm{a}}$ & GP & $>6$ months & n.a. \\
\hline Kohlmann, 1991 & $2 \%$ & Postal & $>1$ month & $20 \%$ \\
\hline Bowsher et al., 1991 & $7 \%$ & Telephone & $>3$ months & $?$ \\
\hline $\begin{array}{l}\text { VonKorff et al., } 1988 \text {, } \\
\quad 1990,1993\end{array}$ & $8 \%$ & Postal & 'Persistent' & $20 \%$ \\
\hline $\begin{array}{l}\text { Frølund and Frølund, } \\
1986\end{array}$ & $9 \%$ & GP & $>3$ months & n.a. \\
\hline Crook et al., 1984 & $11 \%$ & Telephone & $\begin{array}{l}>2 \text { weeks } \\
\text { ('persistent') }\end{array}$ & $5 \%$ \\
\hline Croft et al., 1993 & $13 \%$ & Postal & $>3$ months & $34 \%$ \\
\hline $\begin{array}{l}\text { Magni et al., } 1990, \\
1992^{b}\end{array}$ & $14+20 \%$ & Survey & $>1$ month & $?$ \\
\hline $\begin{array}{l}\text { Andersson et al., 1993; } \\
\text { Andersson, } 1994\end{array}$ & $18 \%$ & Postal & $>3$ months & $15 \%$ \\
\hline Sternbach, 1986 & $10+29 \%$ & Telephone & $>3$ months & $?$ \\
\hline $\begin{array}{l}\text { Mäkélä and } \\
\text { Heliövaara, } 1991\end{array}$ & $17+45 \%$ & $\begin{array}{l}\text { Clinical } \\
\text { examination }\end{array}$ & $?$ & $10 \%$ \\
\hline $\begin{array}{l}\text { Andersen and Worm- } \\
\text { Pedersen, } 1987\end{array}$ & $30 \%$ & Postal & $?$ & $10 \%$ \\
\hline Brattberg et al., 1989 & $40 \%$ & Postal & $>6$ months & $33 \%$ \\
\hline James et al., 1991 & $82 \%{ }^{c}$ & Survey & $\begin{array}{l}\text { No time } \\
\text { limit }\end{array}$ & $30 \%$ \\
\hline
\end{tabular}

${ }^{\mathrm{a}}$ Potter and Jones give the incidence, not the prevalence.

${ }^{b}$ Musculoskeletal and abdominal pain.

${ }^{c}$ Where the prevalence presented is the point-prevalence. James et al. give the life-time prevalence. 
Verhaak, P.F.M., Kerssens, J.J., Dekker, J., Sorbi, M.J., Bensing, J.M. Prevalence of chronic benign pain disorder among adults: a review of the literature. Pain: 1998, 77, 231-239

\section{Table 2}

Prevalence of chronic pain according to the different research methods and definitions of chronic pain used

\begin{tabular}{|c|c|c|c|c|}
\hline \multirow[t]{2}{*}{ Method } & \multicolumn{4}{|c|}{$\begin{array}{l}\text { Pain dura- } \\
\text { tion }\end{array}$} \\
\hline & $\begin{array}{l}>2 \text { weeks } \\
\text { to } \\
>1 \text { month }\end{array}$ & $>3$ months & $>6$ months & Other/? \\
\hline Telephone & $11 \%$ & $7 \%, 10-29 \%$ & & \\
\hline Postal & $2 \%$ & $13 \%, 18 \%$ & $40 \%$ & $8 \%, 30 \%$ \\
\hline Direct interview & $14-20 \%$ & & & $82 \%$ \\
\hline $\begin{array}{l}\text { General practitioner/ } \\
\text { expert }\end{array}$ & & $9 \%$ & $<1 \%$ & $17+45 \%$ \\
\hline
\end{tabular}


Verhaak, P.F.M., Kerssens, J.J., Dekker, J., Sorbi, M.J., Bensing, J.M. Prevalence of chronic benign pain disorder among adults: a review of the literature. Pain: 1998, 77, 231-239

\begin{tabular}{|c|c|c|c|c|c|}
\hline Authors & Research methods & Definition & $\begin{array}{l}\text { Aspects taken } \\
\text { into account }\end{array}$ & Prevalence & $\begin{array}{l}\text { Demographic and } \\
\text { comorbidity } \\
\text { characteristics }\end{array}$ \\
\hline $\begin{array}{l}\text { Andersen and Worm- } \\
\text { Pedersen, } 1987\end{array}$ & $\begin{array}{l}\text { Postal survey Denmark, } \\
19 ? ? 1 \text { region } \\
\text { Open population, } \\
18 \text { yearst } \\
n=3400 \\
\text { Response rate: } 85 \%\end{array}$ & & $\begin{array}{l}\text { Persistent pain: } \\
30 \%\end{array}$ & & \\
\hline $\begin{array}{l}\text { Andersson et al., 1993; } \\
\text { Andersson, } 1994\end{array}$ & $\begin{array}{l}\text { Postal survey Sweden, } \\
19882 \text { regions } \\
\text { Open population, } \\
25-75 \text { years } \\
n=1609 \\
\text { Response rate: } 90 \%\end{array}$ & $\begin{array}{l}\text { Chronic pain: persistent or } \\
\text { recurrent pain, }>3 \text { months, } \\
\text { intensity } 4 / 5 \\
\text { (5-point-scale). } \\
\text { Dysfunctional chronic pain: } \\
\text { persistent or recurrent pain, } \\
>6 \text { months, intensity } 4 / 5 \\
(5 \text {-point-scale), with impairment } \\
\text { of activities of daily life or } \\
\text { sick leave at least once in } \\
\text { last } 3 \text { months }\end{array}$ & $\begin{array}{l}\text { Intensity } \\
\text { Location } \\
\text { Gradation }\end{array}$ & $\begin{array}{l}\text { Pain }>3 \text { months, } \\
\text { any intensity: } 50 \% \\
\text { Chronic pain: } 18 \% \\
\text { Dysfunctional chronic } \\
\text { pain: } 12.8 \%\end{array}$ & $\begin{array}{l}45+-64 \text { years higher } \\
\text { prevalence } \\
25-34 \text { years lower } \\
\text { prevalence } \delta=\subsetneq \\
\text { Blue collar workers } \\
\text { higher prevalence } \\
\text { Especially neck- } \\
\text { shoulder-low back }\end{array}$ \\
\hline Bowsher et al., 1991 & $\begin{array}{l}\text { Telephone survey } \\
\text { Great Britain, } 1990 \\
\text { National } \\
\text { Open population } \\
\text { All ages } \\
n=2942 \\
\text { Response rate: ? }\end{array}$ & $\begin{array}{l}\text { Chronic pain: pain } \\
\text { which has lasted on } \\
\text { and off for longer than } \\
\text { the last } 3 \text { months }\end{array}$ & $\begin{array}{l}\text { Location } \\
\text { Temporal } \\
\text { characteristics } \\
\text { Social disability }\end{array}$ & Chronic pain: $7 \%$ & $\begin{array}{l}\text { Lower SES higher } \\
\text { prevalence } \delta<q \\
\text { Pain was frequently } \\
\text { attributed to arthritis } \\
(44 \%), \text { illness }(8 \%) \text {, } \\
\text { injury }(7 \%), \text { heart }(6 \%) \\
\text { and surgery }(4 \%)\end{array}$ \\
\hline Brattberg et al., 1989 & $\begin{array}{l}\text { Postal survey } \\
\text { Sweden, } 19 ? ? ? \\
\text { Regional } \\
\text { Open population } \\
18-84 \text { years } \\
n=827 \\
\text { Response rate: } 67 \%\end{array}$ & $\begin{array}{l}\text { Pain intensity: } \\
\text { 6-point scale } \\
\text { Pain consequences: } \\
\text { 6-point scale } \\
\text { Obvious pain = intensity } \\
\geq 3 \text { ('like being stiff } \\
\text { after exercise') + } \\
\text { consequences } \geq 4 \text { ('pain } \\
\text { affects to quite a high } \\
\text { degree') }\end{array}$ & $\begin{array}{l}\text { Intensity } \\
\text { Location } \\
\text { Gradation } \\
\text { Temporal } \\
\text { characteristics } \\
\text { Disability }\end{array}$ & $\begin{array}{l}\text { Any kind of pain: } \\
66 \% \\
\text { Obvious pain } \\
>6 \text { months: } 40 \%\end{array}$ & $\begin{array}{l}\text { Obvious pain is more } \\
\text { prevalent in } 45-64 \\
\text { years than in } 18-44 \text { and } \\
65-84 \delta=\uparrow \\
\text { Obvious pain especially } \\
\text { in shoulders, low back, } \\
\text { legs, neck }\end{array}$ \\
\hline Croft et al., 1993 & $\begin{array}{l}\text { Postal survey } \\
\text { England, } 1991 \\
\text { Registered population } \\
\text { of } 2 \text { general practices } \\
18-85 \text { years } \\
n=1340 \\
\text { Response rate: } 66 \%\end{array}$ & $\begin{array}{l}\text { Pain: 'A report of any pain } \\
\text { during the past month which } \\
\text { has lasted for longer than } 24 \\
\text { hours' } \\
\text { Chronic pain: 'pain as defined } \\
\text { above, which started more than } \\
3 \text { months ago' } \\
\text { Widespread pain: 'along the axial } \\
\text { skeleton and in two contralateral } \\
\text { quadrants of the body' } \\
\text { Chronic widespread } \\
\text { pain: 'widespread pain }>3 \\
\text { months' }\end{array}$ & $\begin{array}{l}\text { Location } \\
\\
1 \\
1 \\
1\end{array}$ & $\begin{array}{l}\text { Pain: } 56 \% \\
\text { Widespread pain: } 16 \% \\
\text { Chronic widespread } \\
\text { pain: } 13 \%\end{array}$ & $\begin{array}{l}\text { Chronic widespread } \\
\text { pain increases with } \\
\text { age } \delta<\uparrow \\
\text { Positive association } \\
\text { with: somatic symptoms, } \\
\text { tiredness, affective } \\
\text { symptoms }\end{array}$ \\
\hline Crook et al., 1984 & $\begin{array}{l}\text { Telephone survey } \\
\text { Canada, } 19 ? ? \\
\text { Sample from registered } \\
\text { population of a general } \\
\text { practice } \\
n=827 \\
\text { Response rate: } 95 \%\end{array}$ & $\begin{array}{l}\text { Persistent pain: 'often } \\
\text { troubled with pain and pain in } \\
\text { preceding } 2 \\
\text { weeks' } \\
\text { Temporary pain: 'not } \\
\text { often troubled but pain } \\
\text { in preceding } 2 \text { weeks' }\end{array}$ & Location & $\begin{array}{l}\text { Persistent pain: } 11 \% \\
\text { Temporary pain: } 5 \%\end{array}$ & $\begin{array}{l}\text { Persistent pain: older, } \\
\text { more retired, more } \\
\text { widowed, lower income } \\
\text { than no pain }\end{array}$ \\
\hline $\begin{array}{l}\text { Frølund and Frølund, } \\
1986\end{array}$ & $\begin{array}{l}\text { Registration by } 26 \\
\text { general practitioners in } \\
1 \text { week Denmark, } 1983 \\
2886 \text { consultations } \\
\text { (week prevalence) }\end{array}$ & $\begin{array}{l}\text { Chronic pain: 'pain persisting } \\
\text { for at least } \\
3 \text { months or frequent } \\
\text { exacerbations of an } \\
\text { essentially chronic condition' } \\
\text { Problem cases: 'pain unsolved } \\
\text { and perhaps unsolvable' }\end{array}$ & Location & $\begin{array}{l}\text { Pain in } 22 \% \text { of the } \\
\text { consultations } \\
\text { Chronic pain in } 9 \% \\
\text { of the consultations } \\
\text { Problem cases: } 3.7 \%\end{array}$ & $\begin{array}{l}\text { Female/male ratio } \\
\text { increases with age Acute/ } \\
\text { chronic ratio increases } \\
\text { with age }\end{array}$ \\
\hline
\end{tabular}


Verhaak, P.F.M., Kerssens, J.J., Dekker, J., Sorbi, M.J., Bensing, J.M. Prevalence of chronic benign pain disorder among adults: a review of the literature. Pain: 1998, 77, 231-239

\begin{tabular}{|c|c|c|c|c|c|}
\hline Authors & Research methods & Definition & $\begin{array}{l}\text { Aspects taken } \\
\text { into account }\end{array}$ & Prevalence & $\begin{array}{l}\text { Demographic and } \\
\text { comorbidity } \\
\text { characteristics }\end{array}$ \\
\hline James et al., 1991 & $\begin{array}{l}\text { Psychiatric Interview } \\
\text { (DIS) New Zealand, } \\
\text { 1986 Regional } \\
\text { Open population } \\
\text { 18-64 years } \\
n=1498 \\
\text { Response rate: } 70 \%\end{array}$ & $\begin{array}{l}\text { Q: 'Ever experienced pain, } \\
\text { severe enough to have led to } \\
\text { consultation with a doctor or to } \\
\text { the use of medication or inter- } \\
\text { fered with life or activities a lot?' } \\
\text { Excluded: pain associated with } \\
\text { medication, alcohol or drug use }\end{array}$ & Location & $\begin{array}{l}82 \% \text { reported a life- } \\
\text { time pain experience }\end{array}$ & $\begin{array}{l}\delta<\% ; \wp \uparrow \text { more loca- } \\
\text { tions than } \delta \star \delta ; \text { Pain was } \\
\text { generally attributed to a } \\
\text { physical cause } \geq 30 \% \\
\text { attributed to a psycholo- } \\
\text { gical cause in the follow- } \\
\text { ing cases: menstruation } \\
\text { pain, abdominal pain, }\end{array}$ \\
\hline Kohlmann, 1991 & $\begin{array}{l}\text { Postal survey Germany, } \\
1989 \text { Regional } \\
\text { Open population } \\
26-76 \text { years } \\
n=308 \\
\text { Response rate: } 80 \%\end{array}$ & $\begin{array}{l}\text { Chronic pain: pain in at least } \\
\text { one body region during the last } \\
6 \text { months for more than } 30 \text { days }\end{array}$ & Location & $2.4 \%$ chronic pain & $0<q$ \\
\hline Magni et al., 1990 & $\begin{array}{l}\text { National Health and } \\
\text { Nutrition Examination } \\
\text { Survey I USA, 1971- } \\
1975 \\
\text { Noninstitutionalized } \\
\text { population of USA } \\
25-74 \text { years } \\
n=3023 \\
\text { Response rate: ? }\end{array}$ & $\begin{array}{l}\text { Chronic musculoskeletal pain: } \\
\text { subjects suffering from pain in } \\
\text { the neck, back, hip, knee or } \\
\text { having significant swelling and } \\
\text { pain or joints on most days for } \\
\text { at least } 1 \text { month during the last } \\
12 \text { months }\end{array}$ & $\begin{array}{l}\text { Location } \\
\text { Temporal } \\
\text { characteristics } \\
\text { Sensory }\end{array}$ & $\begin{array}{l}14.4 \% \text { chronic pain, } \\
7.4 \% \text { uncertain ('some } \\
\text { pain but impossible to } \\
\text { determine the duration') }\end{array}$ & $\begin{array}{l}\delta<\uparrow \\
\text { Increase with age } \\
\text { Decrease with income } \\
\uparrow \uparrow, \text { chronic pain, low } \\
\text { income and non-white } \\
\text { race contributed to } \\
\text { depression }\end{array}$ \\
\hline $\begin{array}{l}\text { Mäkélä and Heliövaara, } \\
1991\end{array}$ & $\begin{array}{l}\text { Population survey ( } 2 \\
\text { stage: screening and } \\
\text { physical examination } \\
\text { of the } 52.3 \% \text { who } \\
\text { reported moderate or } \\
\text { severe musculoskeletal } \\
\text { symptoms or impaired } \\
\text { function of at least } \\
\text { one joint) Finland, } \\
1977-1980 \\
30 \text { years and older } \\
n=7217 \\
\text { Response rate: } 90 \%\end{array}$ & $\begin{array}{l}\text { Diagnosis of chronic low back } \\
\text { pain, chronic neck pain, osteo- } \\
\text { arthritis by mobile clinic } \\
\text { physician (no criteria mentioned) }\end{array}$ & $\begin{array}{l}\text { Location } \\
\text { i) }\end{array}$ & $\begin{array}{l}17.1 \% \text { chronic low back } \\
\text { pain } 11.8 \% \text { chronic neck } \\
\text { pain } 15.8 \% \text { osteoarthritis }\end{array}$ & \\
\hline Magni et al., 1992 & $\begin{array}{l}\text { Hispanic Health and } \\
\text { Nutrition Examination } \\
\text { Survey USA, 1982- } \\
1984 \\
\text { Sample of } 76 \% \text { of } \\
\text { Hispanic population } \\
\text { of USA } \\
20-74 \text { years } \\
n=5498 \\
\text { Response rate: ? }\end{array}$ & $\begin{array}{l}\text { Chronic abdominal pain: } \\
\text { abdominal pain or lower chest } \\
\text { pain had been present for at } \\
\text { least } 30 \text { days in the } 12 \text { months } \\
\text { preceding the interview }\end{array}$ & $\begin{array}{l}\text { Location } \\
\text { Temporal } \\
\text { characteristics }\end{array}$ & $\begin{array}{l}5.5 \% \text { chronic abdominal } \\
\text { pain: } \\
4.6 \% \text { of Mexican, } \\
5.8 \% \text { of Cuban, } \\
8.3 \% \text { of Puerto-Rican } \\
\text { population }\end{array}$ & $\begin{array}{l}\delta<\uparrow \\
\text { Higher prevalence among } \\
\text { lower income groups } \\
\text { No age effect } \\
\text { Chronic pain, low } \\
\text { income, not married and } \\
\text { (for Mexican and Cuban } \\
\text { Americans), female sex } \\
\text { contributed to depression }\end{array}$ \\
\hline Potter and Jones, 1992 & $\begin{array}{l}\text { Registration by eight } \\
\text { general practitioners } \\
\text { for } 10 \text { months England, } \\
19 ? ? \\
18-65 \text { years } \\
n=?(8 \text { practices }= \\
\text { approx. } 20000 ?)\end{array}$ & $\begin{array}{l}\text { Pain: new episode of musculo- } \\
\text { skeletal pain of } 4 \text { weeks' } \\
\text { duration } \\
\text { Chronic pain: still pain after } \\
26 \text { weeks, otherwise: } \\
\text { Acute pain }\end{array}$ & $\begin{array}{l}\text { Intensity } \\
\text { Sensory/affective/ } \\
\text { evaluative } \\
\text { Coping }\end{array}$ & $\begin{array}{l}48 \text { patients included } 20 \\
\text { chronic pain, } 25 \text { acute } \\
\text { pain, } 3 \text { no follow-up }\end{array}$ & $\begin{array}{l}\text { Chronic pain more } \\
\text { intense pain than acute } \\
\text { pain } \\
\text { Chronic pain more } \\
\text { depressed than acute pain } \\
\text { Chronic pain more } \\
\text { passive coping strategies } \\
\text { than acute pain }\end{array}$ \\
\hline Sternbach, 1986 & $\begin{array}{l}\text { NUPRIN-survey: } \\
\text { Telephone survey USA, } \\
1985 \\
\text { Open US population } \\
18 \text { years and older } \\
n=1254 \\
\text { Response rate: }\end{array}$ & $\begin{array}{l}\text { Chronic pain: pain for } 101 \\
\text { or more days in the preceding } \\
\text { year }\end{array}$ & $\begin{array}{l}\text { Location } \\
\text { Disability } \\
\text { Severity }\end{array}$ & $\begin{array}{l}10 \% \text { chronic joint pain } \\
9 \% \text { chronic back pain } \\
5 \% \text { chronic headache } \\
5 \% \text { chronic muscle pain }\end{array}$ & $\begin{array}{l}\delta<\uparrow \text { Higher preva- } \\
\text { lence among younger } \\
\text { respondents No income } \\
\text { effect }\end{array}$ \\
\hline
\end{tabular}


Verhaak, P.F.M., Kerssens, J.J., Dekker, J., Sorbi, M.J., Bensing, J.M. Prevalence of chronic benign pain disorder among adults: a review of the literature. Pain: 1998, 77, 231-239

\begin{tabular}{|c|c|c|c|c|c|}
\hline Authors & Research methods & Definition & $\begin{array}{l}\text { Aspects taken } \\
\text { into account }\end{array}$ & Prevalence & $\begin{array}{l}\text { Demographic and } \\
\text { comorbidity } \\
\text { characteristics }\end{array}$ \\
\hline $\begin{array}{l}\text { VonKorff et al., 1988, } \\
1990,1993\end{array}$ & $\begin{array}{l}\text { Mailed questionnaire } \\
\text { USA, } 1986 \\
\text { Sample of enrollees } \\
\text { of HMO } \\
18-75 \text { years } \\
n=1016 \\
\text { Response rate: } 80 \%\end{array}$ & $\begin{array}{l}\text { Pain: pain problems that } \\
\text { lasted a whole day or more, } \\
\text { encountered during the last } \\
6 \text { months }\end{array}$ & $\begin{array}{l}\text { Intensity } \\
\text { Location } \\
\text { Temporal } \\
\text { characteristics } \\
\text { Disability } \\
\text { Interference }\end{array}$ & $\begin{array}{l}41 \% \text { encountered } \\
\text { back pain } \\
26 \% \text { headache } \\
\left(\sigma^{*}<\%\right) \\
17 \% \text { abdominal pain } \\
12 \% \text { facial pain } \\
\left(\sigma^{*}<\%\right) \\
12 \% \text { chest pain } \\
8.1 \% \text { has severe and } \\
\text { persistent pain, all } \\
(4.5 \%)\end{array}$ & $\begin{array}{l}\text { No age effect } \\
\text { Higher prevalence } \\
\text { among lower income } \\
\text { groups } \\
\text { Psychological distress } \\
\text { increases among pain } \\
\text { patients, especially } \\
\text { among those who have } \\
\text { higher levels of non-pain } \\
\text { somatic }\end{array}$ \\
\hline
\end{tabular}

$n$, number of respondents. 